\title{
Joanna Wojdon
}

(Wrocław)

\section{Polityka a szkolna edukacja historyczna}

$*$

$\mathrm{P}$ owiązania polityki z edukacją, polityki z historią, a wreszcie polityki z edukacją historyczną budziły i budzą uwagę nie tylko historyków, badaczy edukacji, polityków, ale także nauczycieli, uczniów, ich rodziców i generalnie - szerokiej opinii publicznej. Niniejszy szkic nie pretenduje do wyczerpania zasygnalizowanego w tytule tematu, ogranicza się jedynie do nakreślenia niektórych problemów w oparciu o przykłady z różnych czasów i miejsc, opisane w literaturze przedmiotu.

Edukacja historyczna pojawiła się już w starożytności, najpierw w Grecji, a następnie w Rzymie ${ }^{1}$. Wspominają o niej w swoich pismach odpowiednio Isokrates oraz Cicero. W obu przypadkach stanowi jeden z elementów kształcenia przyszłej elity: przywódców państwa, mężów stanu. W obu przypadkach występuje jako „nauka pomocnicza” w kształceniu retorycznym: dobrze przygotowany mówca powinien umieć odwołać się do umiejętnie dobranych przykładów z przeszłości. Przykłady te powinny też pomóc ukształtować jego obywatelski charakter ${ }^{2}$.

${ }^{1}$ Nie nauczano jej natomiast w Mezopotamii, gdzie szkoły miały dać praktyczną umiejętność pisania - R. Butts, The education of the West, New York 1973, s. 51. Należała do kanonu lektur w starożytnych Chinach, gdzie edukacja była wstępem do kariery państwowej - T. Lee, Education in traditional China. A history, Leiden-Boston-Koln 2000, s. 365-372.

${ }^{2}$ R. Butts, op. cit., s. 97, 99, 119, 125. 
Poza trywialnym wnioskiem, że edukacja historyczna od swego zarania była ściśle powiązana z polityką, bo z potrzeb politycznych wynikała i miała służyć ich zaspokojeniu, można zadać trzy pytania i sformułować trzy spostrzeżenia dotyczące relacji historii i polityki, które powrócą także w czasach współczesnych:

Pytanie 1: Czy historia ma spełniać jedynie funkcję służebną, czy może być uczona "dla samej siebie”?

Pytanie 2: Komu i/lub czemu ma służyć?

Pytanie 3: Kto decyduje o doborze treści historycznych?

Spostrzeżenie 1: Można mówić o szkolnej edukacji historycznej, nawet gdy historia nie stanowi odrębnego przedmiotu nauczania.

Spostrzeżenie 2: Oddziaływanie między szkolną edukacją historyczną a polityką może być dwukierunkowe. Polityka, potrzeby państwa czy pewnych grup politycznych decydują o tym, jaka historia jest nauczana w szkołach. Z drugiej zaś strony od efektów nauczania (np. od tego, czy i jakie cnoty obywatelskie zostały w jego trakcie uczniom wpojone) zależeć może przyszły kształt polityki państwa, życia politycznego, debaty politycznej.

Spostrzeżenie 3: Już w starożytności dostrzegano rolę nauczyciela, który mógł z historii uczynić przedmiot pasjonujący, poszerzający horyzonty myślowe i rozwijający cnoty wychowanków w oparciu o przykłady z przeszłości, lub pamięciowy koszmar bez większego ładu i składu.

Odpowiedź 1 dla starożytności: Wydaje się, że starożytni widzieli jedynie służebną rolę historii. Miała pomagać kształtować cnoty obywatelskie (służyła więc lepszemu przygotowaniu elity państwa - mamy więc odpowiedź 2 dla starożytności), ale także zrozumieć świat, realny i przedstawiany w tekstach literackich, które uczniowie analizowali ${ }^{3}$. Już w starożytności dostrzegano zresztą niebezpieczeństwa zbytniej „emancypacji” historii: gdy pozornie dla wyjaśniania tekstu zagłębiała się ona w obszerne dygresje na temat na przykład genealogii dynastii czy wybitnych czynów postaci, które uczniowie musieli bezmyślnie wkuwać na pamięć. Taka historia „sama dla siebie” była zmorą uczniów, już przed wiekami krytykowaną przez satyryków ${ }^{4}$.

${ }^{3} \mathrm{~Np}$. A. Corbeil, Education in the Roman Republic: Creating Traditions, [w:] Education in Greek and Roman antiquity, red. Yun Lee Too, Leiden-Boston 2001, s. 266, 282, 284.

${ }^{4} \mathrm{H}$. Marrou, Histoire de l'education dans l'antiquité, tłum. ang.: A history of education in antiquity, London 1956, s. 166. 
Odpowiedź 3 dla starożytności: To prywatny nauczyciel decydował o doborze treści i metodach nauczania, choć były one także przedmiotem publicznej debaty ${ }^{5}$ - o czym świadczą między innymi przytaczane dzieła Isokratesa i Cycerona.

W wiekach średnich i w renesansie, w klasycznym nauczaniu, opartym na sztukach wyzwolonych, informacje o przeszłości pojawiały się na marginesie „przerabianych” lektur i służyć miały ich wyjaśnianiu. Przy czym były to lektury starożytne, a więc i historia także starożytna. Trudno w niej szukać związków z polityką ${ }^{6}$ - przynajmniej w Europie. W państwie Inków nauczanie historii było bowiem wykorzystywane do akulturacji młodych mężczyzn z podbitych przez Inków plemion, zabieranych do Cusco, gdzie zdobywali wykształcenie, potrzebne im potem jako lokalnej elicie ${ }^{7}$.

Elementy dziejów nowożytnych zaczęły się pojawiać dopiero w okresie reformacji, i to w szkołach o charakterze powszechnym. Elita w owych czasach nadal kształciła swoich synów w kanonie klasycznym, ten zaś historię ograniczał do starożytności, a na nowinki otwierał się bardzo powoli i niechętnie ${ }^{8}$. Natomiast prywatne amerykańskie szkoły zawodowe w XVIII wieku reklamowały historię jako przedmiot poszerzający wiedzę każdego,

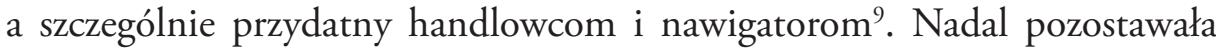
więc poza obszarem zainteresowań polityki.

Sytuacja zmieniła się w XIX wieku, gdy zarówno na kontynencie amerykańskim, jak i europejskim zaczęły kształtować się państwa narodowe. Wspólna przeszłość, obok wspólnego języka, stanowiła podstawowy składnik tworzącej się świadomości narodowej. Nic zatem dziwnego, że znalazła się w obszarze zainteresowania polityków różnego szczebla. Spróbujmy odpowiedzieć na zadane wyżej pytania dla czasów nowożytnych:

Odpowiedź 1: Historia pełni funkcję usługową, aczkolwiek jej zakres merytoryczny staje się znacznie szerszy niż w czasach starożytnych.

Odpowiedź 2: Historia ma pomóc kształtować tożsamość narodową,

5 J. Connolly, Problems of the past in imperial Greek education, [w:] Education in Greek, s. $370 \mathrm{i} \mathrm{n.}$

${ }^{6}$ R. Butts, op. cit., s. 154, 201-207.

7 Ibidem, s. 239.

8 Ibidem, s. 255, 269, 289-290, 345, 349, 390.

9 Ibidem, s. 415. 
poczucie wspólnoty oraz - wraz z całym systemem edukacji - lojalność obywateli wobec państwa.

Odpowiedź 3: W zakresie doboru treści i metod kształcenia różne państwa przyjmowały różne rozwiązania. Najogólniej rzecz biorąc, w państwach scentralizowanych decyzje zapadały na najwyższym szczeblu - jak w Prusach, gdzie o całokształcie edukacji decydował monarcha i jego scentralizowany aparat; natomiast w krajach demokratycznych pozostawały w gestii samorządów w postaci rad szkolnych, z dużą swobodą pozostawianą poszczególnym nauczycielom ${ }^{10}$. Do krajów o najbardziej rozproszonych systemach należały Anglia i Stany Zjednoczone, ale także tam daje się zaobserwować zwiększający się w XIX wieku nacisk na nauczanie historii. Staje się ona odrębnym przedmiotem nauczania - w Stanach Zjednoczonych zasadniczo po wojnie secesyjnej, ale już wcześniej treściami historyczno-obywatelskimi nasycone były czytanki o charakterze ogólnym - i służy przekazywaniu wartości patriotycznych i obywatelskich ${ }^{11}$.

Model edukacji historycznej jako instrument kształtowania tożsamości narodowej został przejęty przez wiele państw narodowych, także tych nowo powstających, zarówno po I wojnie światowej, jak i w wyniku dekolonizacji $^{12}$. Kształt szkolnej historii, zarówno w zakresie celów nauczania, jak i doboru treści, był bardzo wyraźnie wynikiem decyzji politycznych.

Na przykład w Turcji po upadku imperium otomańskiego skoncentrowano się na anatolijskich korzeniach cywilizacji tureckiej, która stamtąd rozprzestrzeniła się na cały świat, będąc początkiem cywilizacji w ogóle. Turków pokazywano więc jako potomków starożytnych Sumerów i Hetytów, a nie niedawno upadłego imperium ${ }^{13}$. Było to całkowite zerwanie $\mathrm{z}$ dorobkiem szkolnej historii czasów otomańskich, która (pod bacznym okiem państwowej cenzury) pomijała aspekt narodowy, a patriotyzm budowała wo-

${ }^{10}$ Ibidem, s. 345, 362.

${ }_{11}$ R. Elson, Guardians of tradition. American schoolbooks of the nineteenth century, Lincoln 1964, s. 5.

$12 \mathrm{O}$ trudnościach $\mathrm{z}$ związanych $\mathrm{z}$ „tanganizacją” historii (np. jak pogodzić sięganie do przedkolonialnej przeszłości z dążeniem do unikania partykularyzmów plemiennych), ale i o determinacji miejscowych władz pisze D. Morrison, Education and politics in Africa. The Tanzanian case, London 1976, s. 216-220.

13 A. Kazamias, Education and the Quest for Modernity in Turkey, Chicago 1966, s. 148; R. Simon, The Teaching of History in Iraq before the Rashid Ali Coup of 1941, „Middle Eastern Studies", 1986, No. 1, s. 43 i przypis 37. 
kół lojalności wobec rozległego wieloczłonowego imperium i osób sułtanów, przedstawianych bez cienia krytyki, raczej jako obiekty kultu niż badań historycznych (niewygodne aspekty ich życiorysów, jak zabójstwa czy choroby psychiczne, pomijano milczeniem $)^{14}$. Szkolne ujęcie dziejów tego samego obszaru zmieniło się zatem diametralnie w wyniku przemian politycznych.

Szkolna historia XX-wiecznej Turcji budowała narodową dumę, a przy okazji realizowała jeszcze jeden cel polityczny: dawanie pocieszenia po świeżym upadku dawnej potęgi państwa ${ }^{15}$. Przed podobnym zadaniem stawała edukacja historyczna także w innych krajach. W NRD historia (i edukacja szkolna w ogóle) starała się przerwać ciągłość historyczną państwa niemieckiego. O Niemczech przed-NRD-owskich pisano jak o państwie obcym, tak jak i o Niemczech Zachodnich, które należały do wrogiego obozu imperialistycznego. Tożsamość narodową i państwową budowano wyłącznie wokół komunistycznych Niemiec Wschodnich ${ }^{16}$. W szkołach brytyjskich dominuje historia społeczna, gospodarcza, przedstawiane są dzieje kultury - co także można uznać za odpowiedź szkolnej edukacji na rozpad imperium ${ }^{17}$. We współczesnej Rosji różne podręczniki przyjmują różne strategie, od gloryfikujących carską i radziecką imperialną przeszłość po bardzo krytyczne wobec ZSRR, a zwłaszcza Stalina i zachęcające uczniów do samodzielnych poszukiwań i dyskusji nad kontrowersyjnymi i nieprzynoszącymi Rosji szczególnej chwały kwestiami z przeszłości (jak choćby sprawa mordu katyńskiego) ${ }^{18}$.

Innego rodzaju wyzwaniem dla szkolnej historii jest radzenie sobie z niedawnymi i/lub bieżącymi konfliktami politycznymi. Kraje byłej Jugosławii,

${ }^{14}$ S. Somel, The modernization of public education in the Ottoman empire. 1839-1908, Leiden-Boston-Koln 2001, s. 194-202.

$15 \mathrm{O}$ terapeutycznej funkcji historii pisze M. Ferro, The use and abuse of history or how the past is taught, Paris 1981, s. VIII.

16 J. Rodden, Textbook Reds. Schoolbooks, ideology and Eastern German identity, University Park 2005, s. 111-136, a zwłaszcza 113-114.

17 T. Haydn, Longing for the past: politicicans and the history curriculum in English schools, 1988-2010, referat podczas konferencji: Longing for the present: the history of history education and the temptations of modernity, Leuven 2010.

18 J. i R. Zajda, The Politics of Rewriting History: New History Textbooks and Curriculum Materials in Russia, „International Review of Education”, 2003, No. 3/4, s. 363-384. Autorzy wskazują równocześnie, że różni politycy mają różną wizję rosyjskiej przeszłości, którą chcieliby upowszechniać w podręcznikach. M. Repoussi, Common trends in contemporary debates on history education, „Yearbook. International Society for History Didactics”, 2008/2009, s. 85 wskazuje, że W. Putin w 2007 roku wyraził podejrzenie, że krytyczne podejście podręczników do radzieckiej przeszłości jest wynikiem zagranicznych grantów, jakie otrzymują ich autorzy. 
państwa bałtyckie, Rosja czy Cypr odwołują się tu nawet do pomocy ekspertów z zewnątrz, niezaangażowanych emocjonalnie, którzy doradzają, w jaki sposób rozmawiać z uczniami o kontrowersjach, mających korzenie w przeszłości. Do ich dyspozycji pozostają programy (i fundusze) pod auspicjami Rady Europy czy Euroclio ${ }^{19}$ - zapobieganie konfliktom i ich rozwiązywanie na drodze politycznej jest przecież ważnym celem politycznym instytucji europejskich. Programy te odżegnują się równocześnie od dążenia do ingerencji w suwerenność zainteresowanych państw. Przedstawiciele instytucji europejskich chcą występować wyłącznie w charakterze doradców, pomagających w wypracowaniu satysfakcjonujących rezultatów samym zainteresowanym ${ }^{20}$.

O tym, że rządzący zdają sobie sprawę z potęgi edukacji historycznej w sytuacjach konfliktowych, świadczyć może fakt, że podręczniki do historii i do wychowania moralnego czy obywatelskiego są zwykle gruntownie badane i „poprawiane” przez zmieniające się władze polityczne. W Japonii po zakończeniu II wojny światowej generał McArthur wręcz wstrzymał na kilka miesięcy nauczanie historii i geografii, dopóki pod ścisłą kontrolą amerykańskiej cenzury okupacyjnej nie opracowano nowych pomocy dydaktycznych, z których usunięto wszelkie odwołania do militarystycznej tradycji japońskiej $^{21}$. Moratorium na nauczanie historii wprowadziły także nowe władze Rwandy po ludobójstwie 1994 roku. Tam utrzymało się ponad 10 lat. Obecnie rządzący dokładają starań, by szkolna historia minimalizowała różnice międzyplemienne - a co więcej, pokazywała je jako wymysł belgijskich kolonizatorów - i budowała wspólnotę państwową. W tym celu ma także sięgać do przedkolonialnych dziejów Rwandy, ukazując je jako okres harmonijnego współżycia klanów, tworzących się w poprzek podziałów etnicznych ${ }^{22}$.

19 Wykaz programów międzynarodowych, regionalnych i krajowych, w które zaangażowana była Euroclio znajduje się na stronach WWW tej organizacji: www.euroclio.eu. Wymienić można np. History in Action - Planning for the Future. Regional Approach for the Learning and Teaching of History in Bosnia-Herzegovina, Croatia and Serbia; Understanding a Shared Past, Learning for the Future (dla Albanii, Bułgarii i Macedonii); Taking the Perspective of the other. Intercultural dialogue, History Teaching and Learning (Cypr); The Integration of Society in Estonia; Macedonia: Retelling the History of a New Nation.

20 Por. np. referat J. van der Loeuw-Roord, Teaching Sensitive and Controversial Issues in History Education, wygłoszony podczas XXI Kongresu Nauk Historycznych w Amsterdamie w 2010 r.

${ }_{21}^{2}$ T. Nishi, Unconditional democracy. Education and politics in occupied Japan, 1945-1952, Stanford 1982, s. 180-184.

22 S. Freedman et al., Teaching History after Identity-Based Conflicts: The Rwanda Experience, „Comparative Education Review”, 2008, nr 4, wydanie elektroniczne z 31 VIII 2008. 
W ten sposób szkolna historia ma służyć politycznemu celowi budowania nowej tożsamości państwowej z pominięciem dawnych różnic etnicznych, kulturowych czy społecznych. Względnie - a przynajmniej czasowo - zabieg taki bywa skuteczny wówczas, gdy oprócz instrumentów politycznych, wpływania na programy nauczania, państwo dysponuje aparatem przymusu, pomagającym wpoić obywatelom ,jedynie słuszne” przekonania. W Izraelu na przykład tego rodzaju bezpośredniego przymusu nie ma. Toteż gdy tam szkolna historia prezentuje dzieje Izraela z jednego tylko, syjonistycznego, punktu widzenia, uwzględniającego dorobek historyczny i cywilizacyjny diaspory żydowskiej na Zachodzie (z pominięciem osiągnięć Żydów w Palestynie oraz Palestyńczyków nieżydowskiej narodowości), okazuje się ona nieskuteczna, również jako instrument integrowania społeczeństwa izraelskiego. W warunkach izraelskich bowiem z przekazem oficjalnym współistnieją różnorakie przekazy prywatne czy medialne i jeśli są one niespójne z wersją szkolną, mocno osłabiają jej wpływ na młode pokolenie ${ }^{23}$.

Ale historia szkolna może nie tylko pocieszać, wyciszać i niwelować. Może wzbudzać pogardę dla innych - na przykład dla Arabów w Izraelu, czarnej ludności w kolonialnej Afryce czy dla państw europejskich w wielu krajach arabskich ${ }^{24}$. Może też wręcz pobudzać do czynu. Weźmy przykład międzywojennego Iraku, który stał się protektoratem brytyjskim. Podobnie jak wiele innych terytoriów zależnych imperium brytyjskiego, w zakresie polityki edukacyjnej cieszył się znaczną autonomią, żeby nie powiedzieć - zupełną samodzielnością 25 . Brytyjczycy mianowali wprawdzie własnego doradcę do spraw edukacji, ale jego rola była właśnie doradcza. Decyzje podejmowali miejscowi urzędnicy, którymi okazali się zresztą imigranci z innych państw arabskich, połączeni wspólnym celem utworzenia z Iraku cze-

23 S. Swirski, Politics and education in Israel. Comparisons with the United States, New York-London 1999, s. 166-167.

${ }^{24}$ Ibidem; P. Zachernuk, African History and Imperial Culture in Colonial Nigerian Schools, „Africa: Journal of the International African Institute”, 1998, nr 4, s. 484-505; M. Ferro, op. cit., s. 54.

${ }^{25}$ O dużej samodzielności w zakresie nauczania ojczystej historii w innej brytyjskiej kolonii, Hongkongu oraz o tym, jak zaowocowało to skrajnie konserwatywnym podejściem do nauczania tego przedmiotu traktują E. Vickers, F. Kan, P. Morris, Colonialism and the Politics of 'Chinese History' in Hong Kong's Schools, „Oxford Review of Education”, 2003, No. 1, s. 95-111; F. Kan, E. Vickers, One Hong Kong, Two Histories: 'History' and 'Chinese History' in the Hong Kong School Curriculum, „Comparative Education”, 2002, nr 1, s. 73-89. 
goś w rodzaju arabskiego Piemontu, wokół którego powstałoby zjednoczone państwo arabskie.

Szkolna historia zaczęła więc szukać historycznych uzasadnień dla postulowanego zasięgu terytorialnego tego państwa (obejmowałoby Półwysep Arabski i obszar "Żyznego Półksiężyca”, z możliwością poszerzenia granic w stronę Azji; Egipt został wyłączony). Unikając elementów otwarcie antybrytyjskich, przedstawiano dzieje cywilizacji semickiej (której częścią była także arabska, ale wcześniej również babilońska, hetycka) jako stojącej na znacznie wyższym poziomie niż europejska: gdy Europejczycy wciąż żyli w jaskiniach, to Semici zakładali miasta i udoskonalali kolejne wynalazki. Z przeszłości Arabów wybierano same sukcesy, a porażki pomijano ${ }^{26}$. Propagowano sylwetki arabskich bohaterów z różnych epok. Eksponowano także konflikty między cywilizacją Wschodu i Zachodu, tak z zamierzchłej przeszłości, jak i niedawne. $Z$ wielką radością odnotowano na przykład zwycięstwo Japonii w wojnie z Rosją w 1905 roku, interpretując je jako pierwszy od dawna tryumf Wschodu nad Zachodem.

Tak skonstruowana edukacja historyczna została uznana przez Brytyjczyków za jeden z czynników, który doprowadził do antybrytyjskiej rewolty w Iraku w 1941 roku (co w sposób dramatyczny potwierdza poczynione na wstępie spostrzeżenie 2, o dwustronnym oddziaływaniu edukacji historycznej i polityki). W ciągu miesiąca powstanie stłumiono, panowanie brytyjskie przywrócono, szkolnictwo zaś poddano ścisłej kontroli Londynu. Dotychczasowi moderatorzy edukacji historycznej zostali - jako imigranci posiadający obce obywatelstwo - wydaleni z Iraku. Nowe programy wprowadziły znacznie więcej niż dotąd historii społecznej i dziejów kultury, mniej zaś elementów politycznych ${ }^{27}$.

Edukacja historyczna w koloniach - to jeszcze jeden obszar badań nad politycznymi uwarunkowaniami szkolnej historii. Tradycyjnie system szkolnictwa w koloniach przedstawiany był jako służący interesom kolonizatorów i kształtujący kolonistów głównie jako lojalną siłę roboczą. Konsekwencją takiego podejścia miał być ogólnie niski poziom edukacji. Szkolna historia zaś

${ }^{26}$ Odwrotnie niż we współczesnym nauczaniu historii w Izraelu, gdzie historia Arabów przedstawiana jako seria rewolucji, zabójstw i wzajemnych porachunków, bez żadnych osiągnięć - S. Swirski, op. cit., s. 167.

27 R. Simon, The Teaching of History in Iraq before the Rashid Ali Coup of 1941, „Middle Eastern Studies", 1986, No. 1, s. 37-51. 
była głównie historią metropolii, ewentualnie kontaktów miejscowej ludności z cywilizacją Zachodu, i pomijała czy wręcz negowała lokalną przeszłość i tradycję - jako niemające podstaw naukowych, oparte na niesprawdzonych ustnych tradycjach i pełne zabobonów ${ }^{28}$.

Nowsze badania wskazują jednak, że jest to obraz uproszczony. Przekonują, że z jednej strony kolonizatorzy starali się wprowadzać pewne elementy lokalne ${ }^{29}$, z drugiej zaś - sami mieszkańcy kolonii niekoniecznie byli zainteresowani zgłębianiem swojej przeszłości, nie istniały też wystarczające badania naukowe. Bronili się oni przed nadawaniem edukacji w koloniach jakiegoś specyficznego, lokalnego charakteru, uważając, że to uczyni ją gorszą od metropolitalnej ${ }^{30}$. Ponadto, gdy certyfikaty potwierdzające ukończenie kolejnych szczebli edukacji wydawane były przez instytucje kolonialne (np. uniwersytet w Cambridge), w oparciu o standardy ogólnobrytyjskie, przeznaczanie czasu na naukę lokalnej historii odbierałoby go przedmiotom egzaminacyjnym, a tym samym zmniejszałoby szanse edukacyjne młodzieży z kolonii ${ }^{31}$.

Także dzisiaj sposób ukazywania przeszłości kolonii budzi liczne spory natury politycznej, zarówno w państwach europejskich, jak i w byłych koloniach. Spory te znajdują odzwierciedlenie między innymi w zmianach szkolnego ujęcia dziejów ${ }^{32}$.

Obok budowania tożsamości narodowej, a więc kształtowania patriotyzmu (czy nacjonalizmu), szkolna historia bywała także nośnikiem innych ideologii, na przykład nazistowskiej albo komunistycznej. W dalszych rozważaniach skupię się na tej ostatniej, nazizm bowiem w szkolnej historii ba-

${ }_{28}$ Np. P. S. Zachernuk, op. cit.; G. von der Muhll, Education, citizenship and social revolution in Tanzania, [w:] Education and political values. An East African case study, red. K. Prewitt, Nairobi 1971, s. 45.

${ }^{29} \mathrm{~Np}$. V. Mallinson, Power and politics in Belgian education 1815 to 1961, London 1963, s. 227.

${ }^{30}$ Np. J. Cameron, W. A. Dodd, Society, schools and progress in Tanzania, Oxford-New York 1970, s. 188-190.

31 K. Prewitt, Political socialization and political education in the new nations, [w:] Education and political values, s. 11.

32 B. Leadbetter, History education and the history wars in Australia, „Yearbook. International Society for History Didactics” 2008/2009, s. 97-108; M. Repoussi, op. cit., s. 81-86. $\mathrm{O}$ zmianie postrzegania okresu kolonialnego w Argentynie pisze M. Rein, Politics and Education in Argentina 1946-1952, Armonk 1998, s. 71-83. 
zował na nacjonalizmie. Odwoływał się do jak najdawniejszych korzeni rasy nordyckiej, a potem narodu niemieckiego. Propagował sukcesy aryjczyków - a więc na przykład dumę z osiągnięć cesarstwa rzymskiego. Ukazywał także sukcesy „rasy panów” w różnych dziedzinach na przestrzeni dziejów ${ }^{33}$.

Komuniści natomiast usiłowali przedstawić na lekcjach historii słuszność marksistowskiej koncepcji następujących po sobie formacji ustrojowych, opartych na podziale pracy i kapitału, począwszy od bezklasowej wspólnoty pierwotnej, przez niewolnictwo, feudalizm, kapitalizm, socjalizm, po mającą dopiero nastąpić epokę komunizmu. Napotykali przy tym jednak rozmaite problemy, związane tak z niedostatkami marksistowskiej historiografii, jak i dydaktyki. Ta pierwsza miała na przykład problemy z ustaleniem cezur czasowych niewolnictwa i feudalizmu w Chinach $^{34}$ (a nie można było w szkolnej historii dopuścić dyskusji czy alternatywnych możliwości, skoro marksizm dawał jedyny słuszny, naukowy wykład dziejów). W Polsce zaś podręczniki przyznawały, że póki co brakuje konkretnych przykładów walki klas w społeczeństwie średniowiecznym, ale to nie dlatego, że walka taka nie miała miejsca, tylko dlatego, że dawni historycy jej nie badali, a na wyniki pracy historyków socjalistycznych trzeba dopiero poczekać35. Problemy dydaktyczne były pochodną merytorycznych i wynikały z trudności wyłożenia zawiłości teorii marksistowskiej dzieciom z V i VI klasy szkoły podstawowej, przy ich możliwościach percepcyjnych, zasobie pojęć oraz przy konieczności skrótowego przedstawiania materiału. Jak wskazują badania dotyczące NRD, taka edukacja skutkowała na przykład przekonaniem, że starożytny Rzym powstał na miejscu Mezopotamii (skoro najpierw omawiano pierwotne społeczeństwo bezklasowe, które w Mezopotamii wyewoluowało w pierwsze społeczeństwo klasowe, a Rzym był kolejnym szczeblem rozwoju) $)^{36}$.

Bardzo szybko w Związku Radzieckim, a także w innych krajach, obok marksizmu pojawiły się elementy narodowe. Próbowano je łączyć z marksistowskimi, w różnych proporcjach w różnych krajach i okresach.

33 J. Rodden, op. cit., s. 116, 121.

${ }^{34}$ C. T. Hu, Orthodoxy over historicity. The teaching of history in communist China, „Comparative Education Review", 1969, No. 1, s. 2-19.

35 Np. G. Missalowa, J. Schoenbrenner, Historia Polski [kl. IV], Warszawa 1951, s. 30.

36 D. F. H. Burrington, Knowledge and allegiance. History teaching in the German Democratic Republic, 1951-71, „Comparative Education”, 1983, No. 1, s. 47-48. 
W Rosji Radzieckiej początkowo w ogóle uznano historię za zbędny dla państwa rewolucyjnego burżuazyjny przeżytek, zastąpiony „politgramotą”, a następnie wiedzą o społeczeństwie („obszczestwowiedieniem”). Szybko jednak do programu owego „obszczestwowiedienia” włożono wydarzenia i postaci z historii Rosji, a patriotyzm rosyjski stał się - obok marksistowskiej wizji walki klas - podstawową osią konstrukcyjną programów nauczania reaktywowanej w latach trzydziestych historii ${ }^{37}$.

W Polsce już w połowie lat pięćdziesiątych podstawą programów i podręczników szkolnych stały się tradycyjnie ujmowane dzieje narodowe, z elementami historii powszechnej (a nie, jak w czasach „ofensywy ideologicznej”, formacje ustrojowe ze wskazaniem, jak przejawiały się one w Polsce), ale wciąż podkreślano rolę „ludu” w różnego rodzaju konfliktach zbrojnych, robotnicze albo chłopskie pochodzenie czy sympatie bohaterów narodowych, braterstwo warstw uciśnionych z różnych krajów, a negatywny charakter reżymów, zaś Polska Ludowa wciąż była zwieńczeniem wcześniejszych dziejów ${ }^{38}$. W NRD jeszcze w latach sześćdziesiątych obowiązywała periodyzacja marksistowska, przy czym dzieje dawniejsze niż XIX wiek kończono omawiać w klasie VI i nigdy więcej do nich nie wracano. Koniec szkoły podstawowej i cała średnia poświęcone były partyjnej interpretacji ostatnich 150 lat $^{39}$. Zupełnie najnowszymi wydarzeniami zajmowała się także historia albańska ${ }^{40}$.

W Chinach Ludowych wkrótce po zwycięstwie rewolucji Mao ogłosił, że historia jest ważnym elementem edukacji szkolnej, co uzasadniał zarówno w sposób negatywny: nie może być tak, że Chińczycy wiedzą więcej o demokracji ateńskiej niż o własnej wielowiekowej przeszłości, jak i pozytywny: Chińczycy mają z czego być dumni w swojej historii i należy te elementy, które mogą budzić narodową dumę, wydobyć i przekazać młodemu pokoleniu. Równocześnie historia miała wpajać uczniom internacjonalizm, kształcić socjalistyczną moralność, analizując sylwetki nowych bohaterów,

37 L. Holmes, The Kremlin and the schoolhouse. Reforming education in Soviet Russia. 1917-1931, Bloomington 1991, s. 35-40, 61, 79-80, 142.

38 Pisałam o tym w: J. Wojdon, Propaganda polityczna w podręcznikach dla szkót podstawowych Polski Ludowej 1944-1989, Toruń 2001.

39 J. Rodden, op. cit.

40 J. Thomas, Education for communism. School and State in the People's Republic of Albania, Stanford 1969, s. 64-65 (materiał nauczania obejmował na przykład kongresy rządzącej partii oraz kolejne plany pięcioletnie). 
wreszcie wychowywać do pracy, pokazując jej rolę w społeczeństwach przeszłości. Ponieważ - tak jak i w innych krajach komunistycznych - uważano, że historyk jest wyrazicielem swojej klasy i formacji politycznej, cały dorobek dotychczasowej historiografii i podręcznikarstwa historycznego został anulowany. Władze zdecydowały, że lepiej używać pisanych naprędce prowizorycznych, ale poprawnych ideologicznie, środków dydaktycznych ${ }^{41}$.

Marksizm z nacjonalizmem łączą także podręczniki do historii w Zimbabwe. Ukazują one przeszłość kolonialną jako okres kolaboracji białych kolonizatorów z uprzywilejowanymi grupami czarnych mieszkańców, przeciw którym słusznie kierował się gniew ogółu rodzimej ludności ${ }^{42}$.

Szkolną historię postrzegano także jako narzędzie do walki z komunizmem. Gdy w USA po „szoku sputnikowym” starano się dotrzymać tempa rozwoju nauce radzieckiej, główne nakłady finansowe poszły na wspieranie przedmiotów ścisłych i przyrodniczych, ale swój przydział otrzymała także historia - jednak nie na nasycenie polityką, lecz na rozwój atrakcyjnych dla uczniów form przekazu. W jakimś zakresie więc tak modne dziś metody aktywizujące są pokłosiem zimnej wojny ${ }^{43}$.

Próbując przyjrzeć się, jak dzisiaj wyglądają relacje między historią i polityką, spróbujmy raz jeszcze odpowiedzieć na postawione we wstępie pytania.

Pytanie 1: Czy historia ma spełniać jedynie funkcję służebną, czy może być uczona „dla samej siebie”?

Wydaje się, że czasy nauki dla samej nauki, dla ogólnego rozwoju intelektualnego, treningu myśli czy pamięci odeszły w przeszłość wraz z umasowieniem edukacji. Nie tylko historia, ale także inne przedmioty szkolne muszą udowadniać swoją praktyczną przydatność. W państwach stawiających na nacjonalizm i na silny związek obywateli z państwem, oparty na poczuciu wspólnego dziedzictwa, waga historii jest niekwestionowana. Ale też posta-

${ }^{41}$ C. T. Hu, op.cit.

42 J. Wassermann i M. Maposa, A historical literacy for patriotic history - Zimbabwean history textbooks circa 1980-2008, referat podczas konferencji Longing for the Present, Leuven 2010.

$43 \mathrm{G}$. Linden, The historical profession in transition. Its response to the challenges of the $1960 \mathrm{~s}$ and 1970s, „The History Teacher”, 1990, No. 3, s. 293-303. Dziękuję Crystal Johnson za zwrócenie uwagi na ten artykuł. 
wione przed nią zadania nie pozostawiają zbyt wiele miejsca na samodzielne dociekanie, różnorodność interpretacji, akademickie zabawy. Wykładnia dziejów jest jedna i narzucona z góry, wcale niekoniecznie przez uczonych historyków (których badania zresztą także są ukierunkowywane).

Tam z kolei, gdzie nacjonalizm ustępuje wielokulturowości, gdzie wolność słowa i przekonań dominuje nad dążeniami do unifikacji, gdzie życie ma się koncentrować na teraźniejszości i przyszłości, historia okazuje się nieprzydatną stratą czasu uczniów. Już na początku XX wieku komisja badająca stan amerykańskiej oświaty i opracowująca strategię jej reform doszła do wniosku, że nauczanie historii jest zbędne (podobnie jak języków klasycznych i algebry). Doceniano potrzebę wychowania obywatelskiego i zdobywania wiedzy o funkcjonowaniu społeczeństwa, ale uważano, że do tego celu lepiej nadaje się przedmiot „nauki społeczne”, który zawierałby część treści historycznych. Zasadniczo historia w USA zachowała swoją odrębność, choć zmniejszono jej wymiar, najczęściej na rzecz właśnie nauk społecznych. Stały się one modniejsze tak na gruncie szkolnym, jak i akademickim ${ }^{44}$.

Są i takie kraje, gdzie historia się nie obroniła, lecz nauczana jest w jednym bloku, na przykład razem z geografią we Francji albo z geografią i wiedzą o społeczeństwie w niektórych landach niemieckich czy jako część nauk społecznych w Kanadzie. Takie umiejscowienie historii jest na ogół (może poza Francja) krytykowane przez historyków, którzy argumentują, że przy braku systematycznego kursu historii w umysłach uczniów nie kształtuje się spójne wyobrażenie o przeszłości, nie rozumieją oni powiązań przyczynowo-skutkowych, a wyrwane z kontekstu exempla pozwalają na łatwą manipulację i raczej indoktrynują niż uczą ${ }^{45}$.

\section{Pytanie 2: Komu i/lub czemu ma służyć?}

W państwach scentralizowanych historia ma służyć zasadniczo interesom państwa i budowaniu tożsamości narodowej lub przynajmniej lojalności państwowej. Bywa także wykorzystywana do wpajania różnego rodza-

${ }_{44}$ D. Nasaw, Schooled to order. A social history of public schooling in the United States, New York 1979, s. 143-144; G. Linden, op. cit.

45 E. Erdmann, Powstanie zintegrowanego przedmiotu G/S/E (historia, wiedza o społeczeństwie i geografia) w Bawarii i doświadczenia z nim zwiąane, [w:] Korelacja - integracja wiedzyszansa dla ucznia, red. G. Pańko, J. Wojdon, Lubin 2006. Por. także: T. Lobbes, History lesson or social studies: The role of the present in the debate on history education in Belgium (1970-1990), referat podczas konferencji: Longing for the present, Leuven 2010; L. Holmes, op. cit., s. 61. 
ju ideologii, propagowanych przez państwo i jego aparat ${ }^{46}$. W dyktaturach może być także wykorzystywana do budowania autorytetu (czy wręcz kultu) jednostki albo grupy sprawującej aktualnie władzę - poza historycznymi przykładami dyktatur komunistycznych albo peronizmu w Argentynie ${ }^{47}$ można tu przytoczyć także dzisiejsze Zimbabwe, gdzie przy ogólnym chaosie gospodarczym i politycznym cezurą końcową podręczników do historii pozostają lata dziewięćdziesiąte i mowa jest o harmonijnym rozwoju kraju pod władzą rządzącej (tej samej wówczas i dzisiaj) partii ${ }^{48}$.

W państwach zachodnich od początku XX wieku, a zwłaszcza w jego drugiej połowie, popularność zdobywały koncepcje upodmiotowienia ucznia w procesie edukacji i uczynienia z jego potrzeb głównego kryterium doboru celów i materiału nauczania ${ }^{49}$. W takim ujęciu historia może być postrzegana jako przekazicielka tradycji, ale także informator o korzeniach współczesnych problemów, a przede wszystkim okazja do przyswojenia przez uczniów umiejętności krytycznej lektury, analizy źródeł, wnioskowania czy argumentowania.

Wydawać by się mogło, że przy tak liberalnej koncepcji edukacji historycznej powinna ona znaleźć się poza wpływami politycznymi. Analiza praktyki szkolnej w demokratycznych krajach Zachodu pokazuje, że nic bardziej mylnego. Nawet gdy nie ma centralnej instytucji wywierającej bezpośrednią presję na treści nauczania, funkcjonują różnorodne grupy nacisku, działają mechanizmy poprawności politycznej, a szkolna historia nadal jest manipulowana, by realizować bieżące cele polityczne.

I tak na przykład krytyk edukacji kanadyjskiej ubolewa, że tamtejsze podręczniki lubują się w wydobywaniu z historii przykładów prześladowania grup etnicznych, zwłaszcza Indian lub ludności murzyńskiej przez białych kolonizatorów, dyskryminacji kobiet czy innych mniejszości. Bohaterami narodowymi dla młodzieży szkolnej nie są już wybitne postaci kanadyjskie-

46 Nie znam badań nad wykorzystaniem szkolnej historii przez grupy wyznaniowe czy ideologiczne do realizacji ich partykularnych celów - ale być może daje się znaleźć i takie przykłady.

${ }^{47}$ M. Rein, op. cit., s. 71-83, 144 pokazuje, że model historii narodowej, stworzony w czasach Perona przetrwał upadek dyktatora, ponieważ w zasadniczych swoich zrębach odpowiadał celom politycznym nowych rządzących. Skrócono jedynie kurs historii narodowej, kończąc go na roku 1943, by nie wspominać o Peronie.

48 J. Wassermann i M. Maposa, op. cit.

49 O tych przemianach i ich konsekwencjach m.in. M. Repoussi, op. cit., s. 76-79. 
go życia politycznego, lecz liderzy walki o równouprawnienie czy też ofiary przemocy na tle rasowym ${ }^{50}$.

Badania niemieckich podręczników do historii starożytnej pokazują z kolei, w jaki sposób dzisiejsze koncepcje zjednoczonej, pozbawionej granic Europy rzutują na przedstawianie młodzieży najdawniejszych dziejów. Miriam Sénécheau śledziła, jak podręcznikowe ilustracje rzymskiego limesu ewoluują od niekończącej się palisady z wieżami strażniczymi, po posterunek będący miejscem wzajemnej wymiany i spotkań, a także wspólnych zabaw dzieci rzymskich i germańskich. Autorka pokazuje także, jak zmieniał się kolor skóry człowieka pierwotnego na podręcznikowych ilustracjach (aż po konkluzję: wszyscy jesteśmy Afrykanami), jak przenosi się dzisiejsze wyobrażenia na przedstawienie europejskiego handlu w epoce brązu czy w czasach rzymskich, jak omawia się „zjednoczenie Europy” przez Celtów czy przypisuje tożsamość europejską odnalezionemu w Alpach zamarzniętemu wędrowcy sprzed 5000 lat $^{51}$.

Co najmniej od końca XX wieku w wielu krajach trwa ostra publiczna debata nad kształtem szkolnej historii i wartości, które ma ona przekazywać. Najogólniej rzecz ujmując, uważane dotąd za nowoczesne „post-narodowe” koncepcje, które zdobywały sobie popularność w drugiej połowie XX wieku, są krytykowane przez konserwatystów, stojących na stanowisku, że celem historii powinno być przede wszystkim budowanie pozytywnej tożsamości narodowej ${ }^{52}$. Można tu przytoczyć batalię o kształt szkolnej historii, rozpoczętą pod koniec XX wieku w Wielkiej Brytanii, gdzie rządzący torysi chcieli doprowadzić do stworzenia ogólnopaństwowej podstawy programowej, odwołującej się do imperialnych tradycji brytyjskich - jeśli chodzi o treści, i do tradycyjnego, chronologicznego ujęcia dziejów - jeśli chodzi o formę nauczania ${ }^{53}$. W Grecji z kolei wydany w 2006 roku podręcznik do historii najnowszej wywołał prawdziwą burzę w mediach, został potępiony podczas nabożeństw kościelnych i ostatecznie wycofany z użycia, ponieważ uznano

50 J. Granatstein, Who killed Canadian history?, Toronto 1998, s. xii-xiv.

${ }^{51}$ M. Sénécheau, Prehistory and the construction of a European identity in German history textbooks today, dostępne pod adresem: www.caen.iufm.fr/colloque_iartem/pdf/senecheau.pdf (data dostępu: 19 XI 2010 r.)

52 S. Popp, National textbook controversies in a globalizing world, „Yearbook. International Society for History Didactics” 2008/2009, s. 109-122; M. Repoussi, op. cit.

${ }^{53}$ K. Crawford, A History of the Right: The Battle for Control of National Curriculum History 1989-1994, „British Journal of Educational Studies”, 1995, No. 4, s. 433-456; T. Haydn, op. cit. 
go za zbyt mało patriotyczny, a za bardzo globalistyczny i proeuropejski ${ }^{54}$. Zażarte debaty o szkolną wizję dziejów toczą się także w Japonii, Indiach i Australiii ${ }^{55}$.

Pytanie 3: Kto decyduje o doborze treści historycznych?

Tak jak w XIX wieku, różne kraje przyjmują tutaj różne rozwiązania, od całkowicie scentralizowanych po zupełnie rozproszone.

Jeśli chodzi o rozwiązania scentralizowane, odgórne, to z historii można przytoczyć stalinowski dekret z 1931 roku, wprowadzający reformę edukacji, który przeciął trwające przez całe lata dwudzieste spory i dyskusje partyjnych pedagogów i historyków, czy i w jakim zakresie potrzebna jest historia jako przedmiot szkolny, oraz określił zakres jej nauczania. Nie trzeba jednak sięgać tak daleko i do tak totalitarnego państwa, jak ZSRR lat trzydziestych, gdyż zaledwie kilka lat temu, w 2005 roku parlament francuski przyjął ustawę, która nakazywała przedstawianie w pozytywnym świetle francuskiej kolonizacji w szkolnej nauce historii ${ }^{56}$.

Na ogół treściami i formami kształcenia zajmują się ministerstwa edukacji i wyodrębnione w nich jednostki organizacyjne. Przedmiotem ich zainteresowania może być minimum programowe i/lub szczegółowe programy nauczania, podręczniki, materiały egzaminacyjne czy zakres kształcenia nauczycieli. Szczególnie istotna wydaje się kontrola podręczników - bo to materiały, z którymi najczęściej pracują nauczyciele i uczniowie. Tutaj kuratela państwa przybierać może różny zakres i stopień szczegółowości. Niektóre państwa pozostawiają szkołom (czy poszczególnym nauczycielom) zupełną swobodę dobierania środków dydaktycznych - spośród dowolnych materiałów dostępnych na rynku, nieposiadających żadnego urzędowego certyfikatu. Inne wprowadzają listy książek rekomendowanych, nadal pozostawiając nauczycielom swobodę wyboru spośród nich lub spoza listy. Kontrola może być

54 W Grecji obowiązuje tylko jeden, ogólnokrajowy, podręcznik dla każdej klasy i przedmiotu nauczania. Jest on zarazem podstawowym materiałem do egzaminów końcowych. Nic zatem dziwnego, że budzi zainteresowanie opinii publicznej. Wojnę, jaką rozpętał ten z 2006 roku, opisuje A. Liakos, History wars - notes from the field, „Yearbook. International Society for History Didactics", 2008/2009, s. 57-74.

55 B. Leadbetter, op. cit., s. 97-108; M. Repoussi, op. cit., s. 81-86.

56 L. Cajani, Historians between wars and criminal laws, „Yearbook. International Society for History Didactics", 2008/2009, s. 45-51 przedstawia kontrowersje wokół tego prawa i innych lois mémorielles przyjmowanych we Francji od 1990 roku. Referat poświęcony temu zagadnieniu wygłosił P. Nora podczas XXI Kongresu Nauk Historycznych w Amsterdamie w 2010 r. 
też negatywna i wskazywać, które książki nie nadają się jako materiały edukacyjne. W wielu krajach panuje model, znany ze współczesnej Polski, gdzie nauczyciel może wybierać z obszernej listy zatwierdzonej przez ministerstwo. Bywa wreszcie i tak, że lista jest krótka i zawiera tylko kilka alternatywnych pozycji lub wręcz - jak w Grecji (i dawniej w krajach „demokracji ludowej”) - jest tylko jeden urzędowo zatwierdzony podręcznik do nauczania danego przedmiotu w danej klasie czy cyklu kształcenia ${ }^{57}$. Ostatnie dziesięciolecia przynoszą coraz większą liberalizację, jeśli chodzi o wpływ państwa na kształt podręczników. Nie tylko przez to, że w krajach postkomunistycznych zaniechano praktyki jednego urzędowego podręcznika, ale także przez to, że rozszerza się model całkowicie wolnorynkowy (z państwowej kontroli zrezygnowano w ciągu ostatnich 20 lat np. w Finlandii, Szwecji i Norwegii) ${ }^{58}$.

W państwach zdecentralizowanych, zwłaszcza federacyjnych, kompetencje w zakresie kontroli edukacji zastrzeżone gdzie indziej dla urzędów centralnych spoczywają często na ich regionalnych odpowiednikach. I tak na przykład w Niemczech każdy land ma własną politykę edukacyjną, podstawę programową, siatkę godzin, programy i podręczniki. W niektórych historia występuje jako osobny przedmiot, w innych - jest „zblokowana” z geografią i wiedzą o społeczeństwie ${ }^{59}$. Podobnie w Kanadzie, edukacja należy do kompetencji władz prowincji. J. Granatstein w swojej pracy Kto zabit kanadyjska historię bardzo krytycznie podchodzi do désintéressement Ottawy wobec treści historycznych, wprowadzanych w poszczególnych prowincjach. Zwraca uwagę, że na przykład Quebec przy okazji wpaja uczniom poglądy separatystyczne: gdy wprowadza odrębny przedmiot: historia Quebecu przy równoczesnym braku historii Kanady. Wskazuje on, że jeśli młodzież nie jest zapoznawana ze wspólnym kanadyjskim dziedzictwem, gdy nie wie nic o politycznych dziejach państwa, jego osiagnięciach jako całości, wówczas nie widzi potrzeby ani sensu utrzymywania jedności państwowej, nie odczuwa żadnego przywiązania do państwa kanadyjskiego ${ }^{60}$.

57 Jak wskazuje S. Popp, op. cit., s. 113-114, wąska lista dopuszczanych do użytku podręczników podnosi temperaturę debaty historycznej w kraju. Tam, gdzie proces dopuszczania do użytku jest rozproszony, a alternatywnych rozwiązań wiele, zainteresowanie opinii publicznej maleje.

58 L. Cajani, History textbooks between teachers' freedom and State control, referat na konferencji Międzynarodowego Stowarzyszenia Dydaktyki Historii, Brunszwik 2009.

59 E. Erdmann, op. cit.

${ }^{60}$ J. Granatstein, op. cit., s. 21-50. 
Pozostają wreszcie kraje, jak USA czy Wielka Brytania, gdzie edukacja jest niemal całkowicie zdecentralizowana, a decyzje zapadają na poziomie zupełnie rozproszonych rad szkolnych, przy minimalnej ingerencji odgórnej. W USA wpływ państwa na kształt szkolnictwa rośnie, ale nie w drodze zmian politycznych, lecz przez zwiększony udział finansów federalnych.

Dobrym przykładem, pokazującym, że nawet tak rozproszony system jak brytyjski może stać się nośnikiem bieżących treści politycznych, może być skuteczność kampanii Związku na rzecz Ligi Narodów, przeprowadzonej w Anglii na początku XX wieku. Związek był organizacją, promującą ideę Ligi Narodów. Poprzez liczne spotkania z radami szkolnymi i samymi nauczycielami, a także z wydawcami podręczników i środków dydaktycznych udało mu się przekonać edukatorów, by w toku nauczania przedstawiali Ligę Narodów (w podręcznikach miał jej być poświęcony przynajmniej jeden rozdział) i to w pozytywnym świetle, by w duchu LN ukazywali stosunki międzynarodowe, a więc na przykład unikali ostrych sformułowań pod adresem Niemców podczas omawiania I wojny światowej. Dopiero w latach trzydziestych kampania straciła nieco na wyrazistości, wobec coraz bardziej oczywistego bankructwa $\mathrm{LN}^{61}$.

Niezmienne pozostaje bowiem spostrzeżenie, że to od nauczyciela w największym stopniu zależy ostateczny kształt szkolnej edukacji historycznej, także w zakresie ulegania wpływom politycznym. Badania pokazują, że nawet w Niemczech hitlerowskich wielu z nich zachowało niezależność i nie wykonywało wszystkich zaleceń dotyczących indoktrynacji młodzieży w procesie nauczania ${ }^{62}$. Podobnie w ZSRR w latach dwudziestych - nauczyciele sabotowali zastępowanie historii „obszczestowiedienijem”, a nawet otwarcie krytykowali takie rozwiązania na łamach prasy pedagogicznej ${ }^{63}$. Brytyjskie władze okupacyjne w Niemczech po II wojnie światowej, dążąc do zmiany sposobu nauczania historii główny wysiłek włożyły w spotkania z nauczycie$\operatorname{lami}^{64}$.

${ }^{61}$ D. Birn, The History Teacher as Propagandist, „The History Teacher”, 1972, No. 4, s. $17-22$.

62 S. Yeger, Education and ideology in the Third Reich in the years 1933-1939: History teaching as a case study, referat podczas konferencji Longing for the Present, Leuven 2010.

${ }^{63}$ L. Holmes, op. cit., s. 37-40.

${ }^{64}$ R. F. Lawson, The English approach in educational reorientation in postwar Germany, [w: Schools in Transition. Essays in comparative education, red. A. Kazamias, E. Epstein, Boston 1968, s. 63-72. 
Naturalnie władze polityczne mogą nauczycieli wychować albo przekupić - płacami albo przywilejami ${ }^{65}$. Mogą też próbować ich zastraszyć, bezpośrednią przemocą - jak w dzisiejszej Rwandzie czy Zimbabwe (skąd pedagodzy masowo uciekają do Republiki Południowej Afryki ${ }^{66}$ ) - albo groźbą odebrania wcześniejszych zdobyczy.

Powyższe rozważania prowadzą do dość pesymistycznego wniosku, że edukacja historyczna jest nierozłącznie powiązana z polityką, a pozbawiona funkcji politycznych okazuje się szkole w ogóle niepotrzebna. O jej celach, treściach i pozycji decydują na ogół politycy, a nie historycy. To, co pozostaje tym ostatnim, to tak kształcić przyszłych nauczycieli, by mimo różnorodnych nacisków byli w stanie zaszczepić swoim podopiecznym rzetelną wiedzę, pasję poznawczą i krytyczne podejście do otrzymywanych przekazów (także politycznych).

${ }^{65}$ D. Abernethy, T. Coombe, Education and politics in developing countries, ibidem, s. $126-140$.

${ }^{66}$ J. Wassermann i M. Maposa, op. cit. 